\title{
PATTERNS OF FOOD RESOURCE USE BY TWO CONGENERIC SPECIES OF PIRANHAS (Serrasalmus) ON THE UPPER PARANÁ RIVER FLOODPLAIN
}

\author{
AGOSTINHO, C. S., ${ }^{1}$ HAHN, N. S. ${ }^{2}$ and MARQUES, E. E. ${ }^{3}$ \\ ${ }^{1,3}$ Núcleo de Estudos Ambientais (Neamb), Fundação Universidade do Tocantins, Setor Jardim dos Ipês, \\ CEP 77500-000, Porto Nacional, Tocantins, Brazil \\ ${ }^{2}$ Universidade Estadual de Maringá, Nupélia, Avenida Colombo, 5790, CEP 87020-900, Maringá, Paraná, Brazil \\ Correspondence to: Carlos Sérgio Agostinho, Núcleo de Estudos Ambientais, \\ Fundação Universidade do Tocantins, Setor Jardim dos Ipês, CEP 77500-000, \\ Porto Nacional, Tocantins, Brazil, e-mail: agostinhocs@ hotmail.com \\ Received May 27, 2002 - Accepted September 5, 2002 - Distributed May 31, 2003
}

(With 2 figures)

\begin{abstract}
Serrasalmus marginatus invaded the Upper Paraná River after construction of the Itaipu Dam in November 1982. This was followed by a reduction in abundance of the native species $S$. spilopleura. Analysis of the pattern of food resource use revealed that both species employ the same feeding strategy, eating mainly fish (whole fish or muscle fragments) and fins bitten off their prey. The diurnal activity period and the feeding rhythm were better-defined in $S$. marginatus. For young individuals of both species, food was taken in a significantly discontinuous manner $(\mathrm{F}=2.83 ; \mathrm{p}<0.05$ and $\mathrm{F}=13.25 ; \mathrm{p}<0.05)$, with a peak at 4 p.m. Ontogenetic differences in diet, the strong feeding overlap of larger individuals of $S$. marginatus and smaller individuals of $S$. spilopleura, and the aggressiveness of $S$. marginatus in establishing feeding territories may have contributed to the success of the invading species.
\end{abstract}

Key words: feeding, feeding rhythm, species introduction.

\section{RESUMO}

Padrões no uso de recursos alimentares, por duas espécies congenéricas de piranhas (Serrasalmus), na planície de inundação do alto rio Paraná

Serrasalmus marginatus invadiu o alto rio Paraná após a construção da barragem de Itaipu, em novembro de 1982. Depois desse evento houve redução na abundância da espécie nativa S. spilopleura. A análise do padrão de utilização dos recursos alimentares revelou que ambas as espécies utilizam as mesmas estratégias alimentares, tendo por alimento principal peixes (inteiros ou fragmentos de musculatura) e nadadeiras arrancadas das presas. Os horários de atividade e a cronologia alimentar diária foram mais definidos para S. marginatus. Entre os jovens, verificou-se que a tomada do alimento foi significativamente descontínua $(F=2,83 ; p<0,05$ and $\mathrm{F}=13,25 ; \mathrm{p}<0,05)$ com um pico às 16 horas, para ambas as espécies. Diferenças ontogenéticas na dieta, forte sobreposição alimentar entre indivíduos de $S$. marginatus de porte maior e $S$. spilopleura menor e agressividade de $S$. marginatus na delimitação de territórios alimentares podem ter contribuído para o sucesso da espécie invasora.

Palavras-chave: alimentação, cronologia alimentar, introdução de espécie.

\section{INTRODUCTION}

Partitioning of resources between coexisting species has been suggested as one of the processes responsible for structuring populations and, consequently, communities. Data compiled by Ross (1986) showed that, contrary to terrestrial organisms for which habitat segregation is more important, 
for assemblages of fishes and other aquatic animals, trophic separation is much more meaningful. According to Gerking (1994), partitioning of food resources is the main factor in the development of fish communities in nearly all aquatic habitats.

In some cases the feeding strategies employed by certain fish species limit their degree of trophic adaptability when confronted with any kind of environmental change. When such a change influences resource availability it results in changes primarily at the organismal level, consequently affecting higher levels such as population and, finally, the community (Piet, 1998).

On the floodplain of the Upper Paraná River, Serrasalmus spilopleura was the only piranha species recorded (Castro \& Arcifa, 1987; Garutti, 1988) until completion of the Itaipu Dam in 1982. This event breached the natural geographic barrier previously formed by Sete Quedas Falls, with consequent mixing of the ichthyofaunas above and below the falls. Thus, $S$. marginatus, which had colonized only the Lower and Middle Paraná, together with 17 other species invaded the upper part of the Paraná floodplain (Agostinho et al., 1994). As a consequence of this environmental disturbance, which according to Drake et al. (1996) had more harmful than beneficial results, the invading piranha species markedly increased in abundance, to the detriment of the native congener.

Based on the interpretations of Gause (1934, apud Schoener, 1970), similar species generally cannot coexist in nature in the absence of ecological differences between them, such as in manners of obtaining most of their food. Thus, was conceivable that the drastic decrease of S. spilopleura might be related to aspects of its trophic ecology.

This study evaluated the diet and daily feeding pattern of S. spilopleura and S. marginatus, with the objective of detecting possible activity period differences and overlapping patterns of food resource use, between the two species.

\section{MATERIAL AND METHODS}

The collections were made on the floodplain of the Upper Paraná River, in the area between the mouths of the Paranapanema and Ivinheima rivers (Fig. 1), where the river anastomoses intricately with the floodplain channels and numerous temporary or permanent lakes. Sampling was carried out monthly over two 24 -month periods (1986-88 and 1992-94). The fishes were caught using fixed nets with mesh sizes of 3 to $16 \mathrm{~cm}$ between opposite knots, set out for 24 hours. During 1986-88 the nets were emptied every 8 hours, and during 1992-94 every 4 hours. For analyses, both periods were included, taking into consideration that the changes in the community after the introduction of the invading species occurred over middle- to long-term.

In the laboratory, the specimens were measured, weighed, and dissected. The stomach contents were identified, and the food spectrum was evaluated by frequency of occurrence and gravimetric methods, combined in the Feeding Index (IAi) (Hynes, 1950; Hyslop, 1980; Kawakami \& Vazzoler, 1980).

The food items were grouped into: fish $=$ muscle fragments and whole fish, fish fins; insects = whole individuals or parts, including larvae and adults of several families; plant matter = leaves, roots, and plant husks; other invertebrates = nematodes, isopods, acari, mollusks, and microcrustaceans; other vertebrates = parts of vertebrates, such as feathers and hairs.

The diet was analyzed by size class of the specimens, with a $2 \mathrm{~cm}$ interval. The smallest specimen measured $2 \mathrm{~cm}$ and the largest $24 \mathrm{~cm}$, for both species. For this analysis, the specimens collected in the 1986-88 period were used, except for the smallest individuals $(2-4 \mathrm{~cm})$, which were from the specimens collected in the 1992-94 period.

The feeding overlap was calculated using the percentage of overlap of Schoener (1970), in which values near zero indicate little feeding overlap, and values near 100 signify very similar diets.

For evaluating daily activity, the absolute number of individuals caught was considered. Feeding pattern evaluation used the variation of the Index of Stomach Fullness. Both analyses were made for each hour over a 24-hour cycle.

The FI represents the relationship between the weight of the stomach and the total weight of the individual (Santos, 1978). These data were submitted to analysis of variance (ANOVA), and the means of the proportions of hourly stomach and fish body weights were compared using Tukey's test (Sokal \& Rohlf, 1995). 


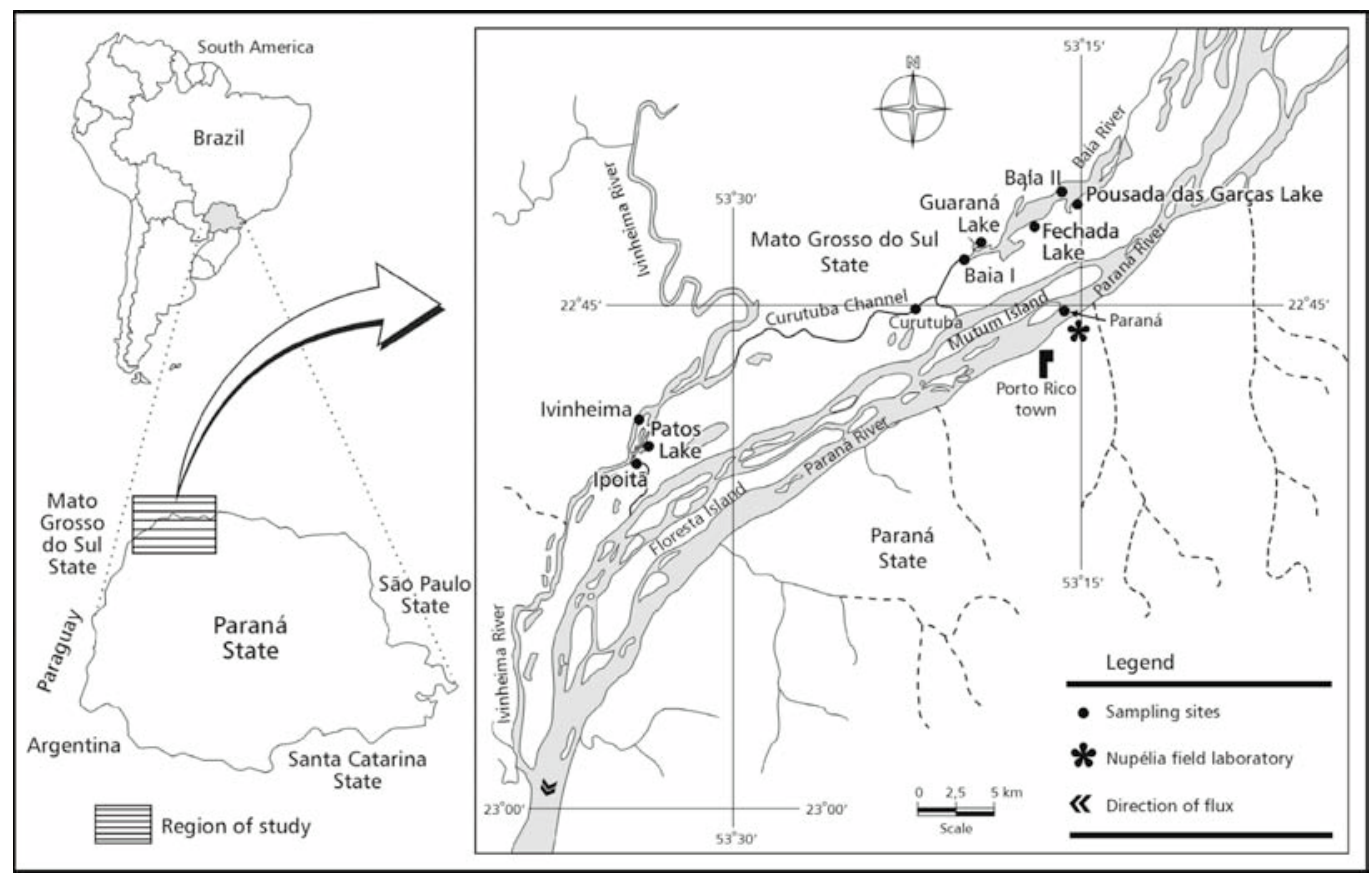

Fig. 1 - Locations of the sampling stations on the floodplain of the Upper Paraná River.

For analysis of daily activity and feeding patterns, the individuals were separated into juveniles and adults according to size (length) at first gonadal maturation, i.e., S. spilopleura (at $9.0 \mathrm{~cm}$ ) and $S$. marginatus (at $9.2 \mathrm{~cm}$ ) (Vazzoler, 1996). The specimens collected during the $1992-94$ period, which had been retrieved from the nets every 4 hours, were used.

\section{RESULTS}

\section{Diet and patterns of feeding overlap}

Because of the restricted and similar feeding spectrum, analyses of 416 stomachs of $S$. spilopleura and 208 of $S$. marginatus showed, that both species employ the same feeding strategy. Fish fins were prominent in the diet of individuals of both species with a standard length of 2 to $4 \mathrm{~cm}$; above this length class, the relative importance of food items differed between the species. Fins continued to be present in high proportions in the stomachs of $S$. marginatus 4 to $8 \mathrm{~cm}$ in length, but after reaching this size all the individuals consumed mainly fish. Individuals of S. spilopleura switched to eating mainly fish after reaching a $4 \mathrm{~cm}$ length (Table 1 ).
The interspecific feeding overlap was greater than $90 \%$ between individuals of the same size class, except for individuals of $S$. spilopleura 4 to $8 \mathrm{~cm}$ long (SP2). These showed higher feeding overlap with $S$. marginatus of the 8 to $16 \mathrm{~cm}$ size class (SM3). There was also a strong overlap between individuals of $S$. spilopleura belonging to length classes 2 to 4 (SP1), 4 to 8 (SP2), and 8 to $16 \mathrm{~cm}$ (SP3), and individuals of $S$. marginatus of greater length classes (Table 2).

\section{Daily activity and feeding patterns}

The most frequent time of capture, for juveniles and adults of both species, was 8 p.m. Adults of $S$. spilopleura were also frequently caught at 8 a.m. and 12 (midnight), and juveniles at 4 p.m. and 12 (midnight). On the other hand, S. marginatus showed a more uniform pattern, with an evident peak at 8 a.m., for both juveniles and adults (Fig. 2).

Analysis of the daily feeding patterns showed that the adult individuals of $S$. spilopleura fed continually $(\mathrm{F}=0.33 ; \mathrm{p}>0.05)$, while adults of $S$. marginatus presented significant peaks $(\mathrm{F}=5.26$; $\mathrm{p}<0.05$ ) of higher feeding intensity, shown using Tukey's test, at 4 a.m., 8 a.m., and 8 p.m. 
TABLE 1

Values of the Feeding Index (IAi) by species and length class (cm).

\begin{tabular}{|l|c|c|c|c|c|c|c|c|}
\hline & \multicolumn{4}{|c|}{ Serrasalmus spilopleura } & \multicolumn{5}{c|}{ Serrasalmus marginatus } \\
\cline { 2 - 10 } & $\mathbf{2 - 4}$ & $\mathbf{4 - 8}$ & $\mathbf{8 - 1 6}$ & $\mathbf{1 6 - 2 4}$ & $\mathbf{2 - 4}$ & $\mathbf{4 - 8}$ & $\mathbf{8 - 1 6}$ & $\mathbf{1 6 - 2 4}$ \\
\hline Fish & 6.71 & 83.90 & 92.91 & 97.63 & 3.52 & 30.27 & 86.84 & 93.75 \\
\hline Fish fins & $\begin{array}{c}93.1 \\
1\end{array}$ & 11.95 & 0.06 & $<0.01$ & 95.41 & 69.61 & 6.94 & 3.08 \\
\hline Insects & 0.02 & 2.92 & 6.02 & 2.02 & 0.42 & 0.12 & 5.45 & 2.77 \\
\hline $\begin{array}{l}\text { Other } \\
\text { invertebrates }\end{array}$ & 0.05 & & & & 0.66 & & & \\
\hline $\begin{array}{l}\text { Other } \\
\text { vertebrates }\end{array}$ & & & 0.29 & 0.15 & & & & \\
\hline Plant matter & 0.12 & 1.22 & 0.72 & 0.19 & 0.01 & $<0.01$ & 0.76 & 0.39 \\
\hline $\begin{array}{l}\text { Examined } \\
\text { stomachs (n) }\end{array}$ & 26 & 19 & 194 & 177 & 115 & 23 & 64 & 6 \\
\hline
\end{tabular}

TABLE 2

Values of the Index of Feeding Overlap of $S$. spilopleura (SP) and $S$. marginatus (SM) by standard length class. Numbers indicate length classes $(1=2-3 ; 2=4-8 ; 3=8-16 ; 4=16-24 \mathrm{~cm})$.

\begin{tabular}{|l|c|c|c|c|c|c|c|c|}
\hline & SP1 & SP2 & SP3 & SP4 & SM1 & SM2 & SM3 & SM4 \\
\hline SP1 & & 18.97 & 6.92 & 6.86 & 96.69 & 76.32 & 14.07 & 9.91 \\
\hline SP2 & & & 87.23 & 85.67 & 15.99 & 42.52 & 94.13 & 88.99 \\
\hline SP3 & & & & 89.92 & 3.61 & 30.46 & 91.45 & 91.77 \\
\hline SP4 & & & & & 3.54 & 30.39 & 90.88 & 94.37 \\
\hline SM1 & & & & & & 73.13 & 10.76 & 7.27 \\
\hline SM2 & & & & & & & 74.12 & 69.56 \\
\hline SM3 & & & & & & & & 95.31 \\
\hline
\end{tabular}

For juveniles of both $S$. spilopleura and $S$. marginatus the pattern in taking food was discontinuous and significant $(\mathrm{F}=2.83 ; \mathrm{p}<0.05$ and $\mathrm{F}=13.25 ; \mathrm{p}<0.05$, respectively), with a well-marked peak at 4 p.m. (Tukey's test) when the stomachs were fullest (Fig. 2).

\section{DISCUSSION}

Although the food resources of S. spilopleura and $S$. marginatus were quite specific and similar (whole fish, muscle fragments, and fins), fish fins were the most important item in the diet of $S$. marginatus; individuals up to $8 \mathrm{~cm}$ long fed mainly on this resource. The principal difference between the diet of the two piranha species was the size above which a certain item comes to be more important dietarily, since $S$. marginatus utilizes fish fins as food over a longer period of time. Ontogenetic changes in the feeding of piranhas were also observed in the Venezuelan Llanos by Nico \& Taphorn (1988) and Winemiller (1989). The advantages of fish fins as food include their abundance and being a renewable resource (1 to 6 weeks; Sazima \& Pombal, 1988). Moreover, fins are more easily digested than are fishbones (Nico \& Morales, 1994). 

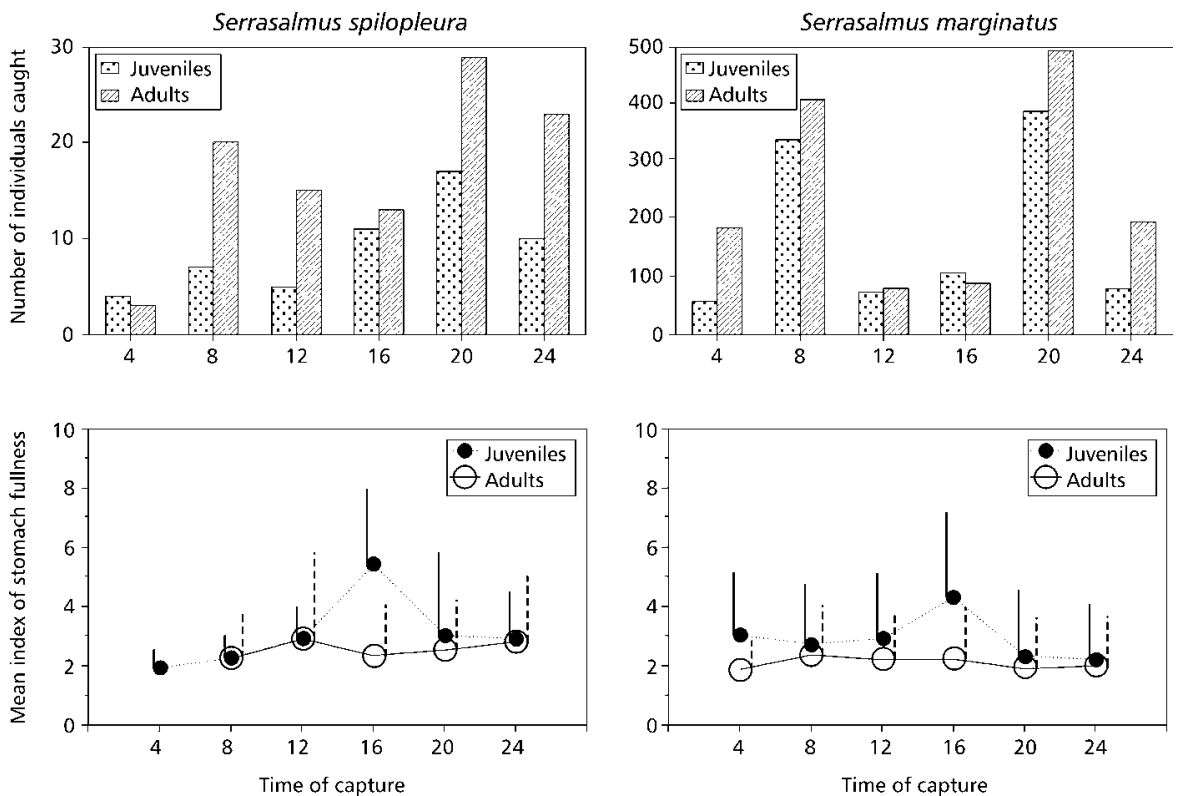

Fig. 2 - Number of individuals caught and variation in the Mean Index of Stomach Fullness for juveniles and adults of $S$. spilopleura and $S$. marginatus. The vertical lines correspond to the standard deviation.

The sequence of microcrustaceans, fish fins, and fish (whole or fragments) as the main food items during different developmental phases, appears to be the general pattern for most species of Serrasalmus (Nico \& Taphorn, 1988; Sazima \& Machado, 1990). Microcrustaceans were not important in the diet of the two species in this study, and were included in "other invertebrates". However, their true importance could not be verified, because only fishes longer than $2 \mathrm{~cm}$ were analyzed.

The aggressiveness of $S$. marginatus in defending its feeding territory (Sazima \& Machado, 1990 ) and the strong feeding overlap between $S$. spilopleura of a given length class and $S$. marginatus belonging to one or two classes larger, may have conferred a competitive advantage on the latter species, in both choice and capture of food. According to Persson (1985) and Peckarsky (1991), larger individual size may confer an advantage in interspecific competition. Nico \& Taphorn (1988) observed that although there was considerable feeding overlap among the piranha species of the lower Venezuelan Llanos, interspecific competition for food was not important because of the large amount of food available. This was probably not the case for the two species considered here. $S$. marginatus is a solitary species and establishes feeding territories of 3 to $4 \mathrm{~m}^{2}$; it is displaced from its territory only by individuals of $S$. spilopleura, which are $30 \%$ to $50 \%$ larger (Sazima \& Machado, 1990). Therefore, the increase in abundance of the invading species, with the consequent delimiting of new feeding territories, probably eventually limited feeding by S. spilopleura.

Competition for food between species using the same resources may be avoided by temporal and/or spatial segregation of the individuals. Comparison of the activity periods of $S$. spilopleura and $S$. marginatus revealed that the latter species had a more defined pattern, although both were active at about 8 p.m. $S$. marginatus also showed a more defined feeding pattern. Almeida et al. (1998), who studied the feeding activity of $S$. marginatus on the Upper Paraná River floodplain, reported similar results. In contrast to the adults, juveniles of both species showed a similar, defined pattern of feeding activity, with a peak only at 4 p.m. hours. This more limited feeding period of the juvenile piranhas may have adaptive significance as it prevents predation by adults of the same or other piscivorous species (Almeida et al., 1998). 
Considering the activity periods and the feeding pattern, the ontogenetic differences in diet, the strong similarities in diet between larger individuals of $S$. marginatus and smaller $S$. spilopleura, and the aggressiveness of $S$. marginatus in establishing feeding territories, it can be inferred that all these factors in conjunction contributed to the success of the invading species in colonizing the Upper Paraná River. Data recently obtained through experimental catches indicate that these conditions continue on the floodplain, since $S$. marginatus was among the most abundant species and $S$. spilopleura was considered rare (UEM, Nupélia/Peld, 2000).

Analyses of the changes in abundance of $S$. spilopleura after the invasion of $S$. marginatus on the Upper Paraná River floodplain, and of the reproductive patterns of both species, related to the success of the invading species, were carried out by Agostinho \& Júlio Jr. (2002) and Agostinho (2003), respectively. The coexistence of these species in this ecosystem may depend upon the capacity of S. spilopleura to behave as a fugitive competitor, until their reproductive patterns and use of food resources become differentiated.

Acknowledgments - We thank John A. Prentice and Rafael J. de Oliveira for helpful comments on the manuscript. We also thank the multidisciplinary team of the Research Nucleus in Limnology, Ichthyology, and Aquaculture (Nupelia) for data and support.

\section{REFERENCES}

AGOSTINHO, A. A., JÚLIO-Jr., H. F. \& PETRERE-Jr., M., 1994, Itaipu reservoir (Brazil): impacts of the impoundment on the fish fauna and fisheries. In: I. G. Cowx (ed.), Rehabilitation of freshwater fishes. Fishing News Book, Bodman, pp. 171-184.

AGOSTINHO, C. S. \& JÚLIO-Jr., H. F. (2002), Observation of an invasion of the piranha Serrasalmus marginatus into the Upper Paraná River, Brazil. Acta Scientiarum.

AGOSTINHO, C. S. (2003), Reproduction of piranhas Serrasalmus spilopleura and Serrasalmus marginatus into the Upper Paraná River, Brazil. Brazilian Journal of Biology.

ALMEIDA, V. L. L. de, HAHN, N. S. \& AGOSTINHO, C. S., 1998, Stomach content of juvenile and adult piranhas (Serrasalmus marginatus) in the Paraná Floodplains, Brazil Stud. Neotrop. Fauna Environ., 33: 100-105.

CASTRO, R. M. C. \& ARCIFA, M. S., 1987, Comunidades de peixes de reservatórios no sul do Brasil. Rev. Bras. Biol., 47(4): 493-500.

DRAKE, J. A., MOONEY, H. A., DI CASTRI, F., GROVES, R. H., KRUGER, F. J., REJMÁNEK, M. \& WILLIAMSON, M., 1996, Biological invasions. John Wiley \& Sons, New York, 525p.

Braz. J. Biol., 63(2): 177-182, 2003
GARUTTI, V., 1988, Distribuição longitudinal da ictiofauna em um córrego da região noroeste do Estado de São Paulo, bacia do rio Paraná. Rev. Bras. Biol., 48(4): 747-759.

GERKING, S. D., 1994, Feeding ecology of fish. Academic Press, London, 416p.

HYNES, H. B. N., 1950, The food of freshwater Sticklebacks (Gaterosteus aculeatus and Pigosteus pungitius), with a review of methods used in studies of the food of fishes. $J$. Anim. Ecol., 19(1): 36-56.

HYSLOP, E. P., 1980, Stomach contents analysis, a review of methods and their application. J. Fish Biol., 17: 411-429.

KAWAKAMI, E. \& VAZZOLER, G., 1980, Método gráfico e estimativa de índice alimentar aplicado no estudo de alimentação de peixes. Bol. Inst. Oceanogr., 2(29): 205207.

NICO, L. G. \& MORALES, M. de, 1994, Nutrient content of piranha (Characidae, Serrasalminae) prey items. Copeia, 2: $524-528$

NICO, L. G. \& TAPHORN, D. C., 1988, Food habits of piranhas in the low llanos of Venezuela. Biotropica, 20(4): 311-321.

PECKARSKY, B. L., 1991, Mechanisms of intra and interspecific interference between larval stoneflies. Oecologia, 85: 521529.

PERSSON, L., 1985, Asymmetrical competition: are larger animals competitively superior? American Naturalist, 126: 261-266.

PIET, G. J., 1998, Impact of environmental perturbation on a tropical fish community. Can. J. Fish. Aquat. Sci., 55: 18421853.

ROSS, S. T., 1986, Resource partitioning in fish assemblages: a review of field studies. Copeia, 2: 352-388.

SANTOS, E. P. dos, 1978, Dinâmica de populações aplicada à pesca e piscicultura. HUCITEC/EUSP, São Paulo, 129p.

SAZIMA, I. \& MACHADO, F. A., 1990, Underwater observations of piranhas in western Brazil. Environ. Biol. Fishes, 28: 17-31.

SAZIMA, I. \& POMBAL-Jr., J. P., 1988, Mutilação de nadadeiras em carás, Geophagus brasiliensis, por piranhas, Serrasalmus spilopleura. Rev. Bras. Biol., 48(3): 477-483.

SCHOENER, T. W., 1970, Non-synchronous spatial overlap of lizards in patchy habitats. Ecology., 51: 408-418.

SOKAL, R. R. \& ROHLF, F. J., 1995, Biometry: the principles and practice of statistics in biological research. $3^{\text {rd }}$ ed. W.H. Freeman, New York, 887p.

UNIVERSIDADE ESTADUAL DE MARINGÁ: Núcleo de Pesquisas em Limnologia, Ictiologia e Aquicultura, 2000, Remanescente de Várzea do rio Paraná. Relatório PELD 2000. Maringá, PR. Disponível em http: <www.nupelia.uem.br>. Acesso em: 30/4/2002.

VAZZOLER, A. E. A. M., 1996, Biologia da reprodução de peixes teleósteos: teoria e prática. EDUEM, Maringá/SBI, São Paulo, 169p.

WINEMILLER, K. O., 1989, Patterns of variation in life history among South American fishes in seasonal environments. Oecologia, 81: 225-241. 